\title{
ENERGY EFFICIENCY OUTLOOK IN CHINA'S URBAN BUILDINGS SECTOR THROUGH 2030
}

\author{
Michael A. McNeil ${ }^{\mathrm{a}}$ \\ Wei Feng ${ }^{\mathrm{a}}$ \\ Stephane de la Rue du Can ${ }^{\mathrm{a}}$ \\ Nina Zheng Khanna ${ }^{a}$ \\ Jing $\mathrm{Ke}^{\mathrm{a}}$ \\ Nan Zhou ${ }^{\mathrm{a}}$ \\ ${ }^{a}$ Energy Analysis and Environmental Impacts Division \\ Energy Technologies Area \\ Lawrence Berkeley National Laboratory \\ 1 Cyclotron Road, MS 90R2121 \\ Berkeley, CA USA 94720 \\ Email: sadelarueducan@lbl.gov \\ Phone: (1) 5104867762
}

\section{ABSTRACT}

This study uses bottom-up modeling framework in order to quantify potential energy savings and emission reduction impacts from the implementation of energy efficiency programs in the building sector in China. Policies considered include (1) accelerated building codes in residential and commercial buildings, (2) increased penetration of district heat metering and controls, (3) district heating efficiency improvement, (4) building energy efficiency labeling programs and (5) retrofits of existing commercial buildings.

Among these programs, we found that the implementation of building codes provide by far the largest savings opportunity, leading to an overall $17 \%$ reduction in overall space heating and cooling demand relative to the baseline. Second are energy efficiency labels 
with $6 \%$, followed by reductions of losses associated with district heating representing $4 \%$ reduction and finally, retrofits representing only about a $1 \%$ savings.

Keywords: Energy efficiency policy, energy demand modeling, Building sector China

\section{INTRODUCTION}

As part of its 11th Five-Year Plan (FYP) from 2006 to 2010, the Chinese government set for the first time a binding target for energy efficiency by requiring a $20 \%$ reduction in energy intensity per unit of gross domestic product (GDP) from 2005 to 2010 and began initiating sector-specific policies and measures to support further reductions in energy and carbon dioxide $\left(\mathrm{CO}_{2}\right)$ intensity through 2020 . China has set continuing binding targets of $16 \%$ and $17 \%$ reductions in energy and carbon intensity per unit of GDP respectively, for its 12th Five-Year Plan (FYP) period from 2011 to 2015. More recently, on June 2015 , China restated in its "intended nationally determined contribution" (INDC) its previously announced goal to peak its emissions around 2030 and lower the carbon intensity of GDP by $60 \%$ to $65 \%$ below 2005 levels by 2030 .

In light of these recent binding targets, evaluating and quantifying the impact of different policies in different sectors become increasingly important, both to guiding the development of near-term policies and prioritizing between them. While targets 
constitute an essential framework for action, energy savings originates from the implementation of policies and programs at the sectoral level. The goal of this paper is to quantify the significant contribution that can deliver specific energy efficiency programs in the building sector and quantify these impacts measured against energy savings target allocation. Description of 'best practice' energy efficiency building programs and policies implementation is available in Levine et al. (2012). Li and Shui (2015) provide a recent analysis of programs and policies implemented in the building sector in China. Policies considered include (1) enforcement of existing building codes and (2) increased penetration of district heat metering and controls, (3) increased penetration of high efficiency district heating generation and distribution, (4) promotion of building labeling programs and (5) existing building retrofits.

The past decade has seen the development of various scenarios describing long-term patterns of China's future energy consumption and GHG emissions. Some of the most notable of these include the International Energy Agency (IEA)'s World Energy Outlook 2013, (IEA, 2013), China's Energy Research Institute (ERI) (CEACER, 2009) and McKinsey \& Company (McKinsey, 2009). In general, the models used in these assessments provide interesting discussions and insights on understanding China's medium and long term energy and carbon emission trajectory from the macro-level. These modeling studies take a top-down or hybrid approach with primarily economic-based drivers. More recently, Yu et al. (2014) developed a detailed building energy model to insert in an integrated assessment framework. While this allowed a more robust analysis of trends in that sector, the building end-use technologies representation is too limited to 
quantify the impacts of building energy efficiency programs. Similarly, the recent IEA's publication on Building Energy Use in China done jointly with Tsinghua University (IEA, 2015) provides great insights on data for key cities and gives a useful description of emerging technologies but does not assess specific policies and programs impacts.

By contrast, the approach taken by Lawrence Berkeley National Laboratory (LBNL)'s China 2050 Model (Zhou et al., 2011a) is to forecast sector energy consumption as driven by the diffusion of various types of equipment; the performance, saturation, and utilization of which has a profound effect on energy demand. Using this bottom-up model, LBNL has undertaken various studies to perform retrospective and prospective sectoral and cross-cutting policy impact evaluation and to develop medium- and longterm outlooks for low-emissions pathways (Zhou, 2011a; Zhou et al., 2007 and 2012). Recently, Xiao et al (2014), developed a bottom-up model to assess the carbon abatement potential and marginal abatement cost (MAC) of 34 selected energy-saving technologies/measures for China's building sector.

Zhou et al. (2012) performed a retrospective analysis of impacts based on actions taken during the 11th Five Year Plan and presented a bottom-up methodology of energy enduse demand to quantify the achievements of building energy efficiency policies during the 11th FYP. The study concluded that with this portfolio of policies, the Chinese government was on track to save 90 Metric Tons Carbon Equivalent (Mtce) by the end of 2010 , or $90 \%$ of its goal. The majority of those savings (62 Mtce) were achieved by the successful tightening of enforcement of existing building codes. 
The current study applies and expands this bottom-up methodology to the question of future savings potential in the building sectors if current policies are continued and strengthened. Using LBNL's China 2050 Model business as usual (BAU) scenario, this study estimates the energy savings potential for 5 programs in the residential and commercial building sectors and provides a detailed analysis of the end-use technologies savings assessments used as assumptions in the model.

This paper is divided into five sections. Following this introduction, Section 2 presents the policies to be evaluated and summarizes the impacts of these policies during the 11th FYP. Section 3 describes the methodology for forecasting energy end use demand and Section 4 describes the assumptions and parameters used to construct each policy scenario. Results and conclusions are shown in Section 5.

\section{BUILDINGS EFFICIENCY POLICIES IN CHINA}

The purpose of the current study is to look forward to ways of achieving as yet uncaptured savings from energy efficiency policies in the building sector. Taking a longterm view, we model the potential savings from an aggressive set of policies targeting conventional, well-known energy efficiency technologies, in order to show feasible energy and emissions reductions versus Business as Usual (BAU) by 2030. The approach is to look at those measures that are judged feasible to implement in China in the near to medium term, with technologies that are already available on the market and that are cost-effective. For this reason, the results may be considered to be conservative. 
The current analysis focuses on policies that target space heating and cooling energy. Lighting and appliances policies are not covered here. The impact analysis covers the five following policies:

- Accelerated Building Codes (Residential and Commercial) - Building codes affect new building heating and air conditioning loads by increasing the requirement of insulation of the building shell and heating, ventilation and air conditioning (HVAC) system efficiency. The policy considered is an acceleration of the update of building codes in China, towards alignment with levels defined by the American Society of Heating, Refrigeration and Air-Conditioning Engineers (ASHRAE), and subsequent updating of those codes through 2030.

- District Heat Metering and Controls (Residential) - Historically, district heat feeding residential buildings in China was not metered or controllable by residences, leading to significant heat waste. Controls and metering are standard on new buildings. The policy considered fills gaps in controls and metering through retrofits of existing buildings to allow for reduction of heating use by residents. This policy does not affect commercial buildings, which are generally fitted with heating controls and metering by default.

- District Heating Efficiency Improvement (Residential and Commercial) - This policy is defined by increased penetration of high efficiency district heating generation and distribution. Improvements considered are (1) increased plant 
efficiency (2) reduction of thermal losses in pipelines and (3) increased pumping station efficiency.

- Energy Efficiency Labels (Residential and Commercial) - This policy assumes increased construction of 5-star buildings as defined by the Ministry of Housing, Urban-Rural Development's (MoHURD) Building Energy Efficiency (BEE) labeling program. The BEE label evaluates buildings on a scale of one (least efficient) to five stars (most efficient) in terms of energy efficiency, with a focus on HVAC system efficiency, compulsory standard compliance, and optional building efficiency measures.

- Retrofits (Commercial) - This policy assumes an increased number of commercial building retrofits. Retrofit measures include improved building envelope (insulation, windows, shading and air-tightness), controls, and heating systems (boilers) in commercial buildings. Commercial buildings usually have larger internal heat load intensity (from lighting, equipment, occupants) compared with residential buildings and therefore the heating retrofit may not be that effective compared with a residential building.

\section{BUILDING ENERGY END USE MODELING}

This study uses the baseline scenario called Continued Improvement Scenario (CIS) of the China Energy Model described in Zhou et al. (2011a). 
LBNL's approach to modeling energy demand growth and reduction potentials uses a bottom-up approach which characterizes energy usage at the 'technology' level (McNeil et al. 2008 and 2012; Zhou et al., 2011a). The model includes the following macroeconomic drivers that affect the evolution of energy demand in China's buildings sector:

- continuous trend toward urbanization

- continuous, but slowing growth in commercial building construction

- Growing uptake and use of energy-consuming appliances by households with increasing income

- Gradually increasing improvement in equipment efficiency and building shell insulation

Rapid GDP growth is expected to continue for the next decade, but will gradually slow by 2020 as the Chinese economy matures and shifts towards a service-based orientation. Different rates of GDP growth were assumed for the periods between 20102020 and 2020-2030 as shown in Table 1.

Besides economic growth, another key driver is the urbanization rate and growth of the urban population. China as a developing country has and will continue to undergo changes in its physical built environment as a result of rapid urbanization. Over 290 million new urban residents have been added from 1990 to 2007, and 380 million new urban residents are expected from 2007 to 2030. The addition of new mega-cities and second-tier cities will drive commercial and residential demand for energy services and 
infrastructure development. To account for the potential effects of urbanization on buildings energy demand, the model uses widely accepted population growth projections from the United Nations and ERI's urbanization assumptions as macrodrivers in all scenarios.

\section{Table 1 - Macroeconomic driver assumptions for all scenarios}

End-use based modeling methodology serves as the basis for the quantitative evaluation of the potential energy and carbon impacts of China's building policies. By adopting an end-use approach to energy and emissions modeling and multiple scenarios to characterize the different paces of policy implementation, this study is able to separate out and isolate the effects of a specific policy or bundle of policies on potential energy savings and energy-related $\mathrm{CO}_{2}$ emission reductions.

The largest energy end use in buildings is HVAC. We consider policy impacts on heating and air conditioning, including district heating, from improvements in equipment and the building envelope. Policies that affect smaller appliances within buildings or are targeted towards improving equipment efficiency only are not included, but covered elsewhere in studies of 'appliance' policies (see for example Zhou et al., 2011b).

\section{POLICY IMPACt MOdELING}

As a first step, we extracted estimates of floor space by building type (residential or commercial), heating type (district heat or stand-alone), equipment type and fuel, and climate zone from LBNL's China 2050 model. In addition, we modeled building 
construction and retirements in order to distinguish between building stock impacted by construction policies and those affected by retrofits. We then created policy scenarios by specifying the amount of floor space affected and the percentage reduction in heating and cooling energy in each year for each policy considered. Estimates of energy savings for building codes and retrofits relied on detailed models of heating and cooling load for prototype buildings using the US Department of Energy (DOE)'s EnergyPlus ${ }^{1}$ building simulation software. Savings for energy efficiency labels followed the definitions of current programs in China.

Two important overarching assumptions were made in modeling building policies:

- Buildings policies are assumed to impact urban buildings only.

- Building policies affect either existing buildings (i.e. retrofits) or new construction only (codes and labels)

While the authors do not suggest that only urban buildings are important users of energy and uniquely appropriate for energy efficiency policy in China, historically, efficiency of rural buildings has been much less studied. As a result, data in the rural subsector is much more sparse, and the feasibility of policy implementation there is much less certain, and they are omitted on these grounds. Generally, for each building affected, each policy type improves the efficiency of either heating or cooling by the unit improvement $\phi i(y)$, where i denotes either heating or cooling. Unit improvement is a percentage that can vary over year $y$, as in the case of building codes, which are

\footnotetext{
${ }^{1}$ EnergyPlus version 8.1, described at http://apps1.eere.energy.gov/buildings/energyplus/
} 
updated periodically. The percentage of buildings effected, or penetration rate is denoted $\psi(y)$.

In the case that a given policy affects both existing and new buildings, energy savings is given by:

$$
E_{\text {policy }}^{i}(y)=E_{B A U}^{i}(y) \times \phi^{\mathrm{i}}(y) \times \psi(y)
$$

Where is $E_{B A U}^{i}$ is energy consumption for cooling or heating in the BAU scenario taken from LBNL China model (Zhou, 2011a) and $\mathrm{E}^{\mathrm{i}}$ policyis the resulting energy consumption after policy implementation.

For policies that affect only new buildings, unit improvement and penetration rates apply to new construction only. The effect of these policies on the total building stock is therefore given by:

$E_{\text {Policy }}^{i}(y)=E_{\text {BAU }}^{i}(y) \times \sum_{y^{\prime}=2015}^{y} \phi^{\mathrm{i}}\left(y^{\prime}\right) \times \psi\left(y^{\prime}\right) \times$ construction $\left(y^{\prime}\right) / \operatorname{stock}\left(y^{\prime}\right)$

\subsection{ACCELERATED BUILDING CODES (RESIDENTIAL AND COMMERCIAL)}

We modeled building code impacts using the simulation tool EnergyPlus. We assume that the existing building stock in northern China was in average built according to the 
building energy code of 19802. In order to model energy consumption of such a building, we use a prototype eight-story high-rise residential building $i$ with window to wall ratio (WWR) of 0.15 . In the Hot Summer Cold Winter (HSCW) climate region for example $^{3}$, the exterior wall is modeled as lacking an insulation layer and having a $\mathrm{U}$ value of $2 \mathrm{~W} /\left(\mathrm{m}^{2} \mathrm{~K}\right)$. The, roof $\mathrm{U}$-value of $1.5 \mathrm{~W} /\left(\mathrm{m}^{2} \mathrm{~K}\right)$ and exterior window $\mathrm{U}$-value of 6.4 W/( $\left.\mathrm{m}^{2} \mathrm{~K}\right)$. The building's air-tightness is modeled at 2 air changes per hour (ACH).

New buildings (at year 2010) are modeled to have the similar characteristics as the current Chinese residential building code JGJ 26 and JGJ 134, prescribed as having exterior wall, roof, and window U-values of $0.7 \mathrm{~W} /\left(\mathrm{m}^{2} \mathrm{~K}\right), 0.6 \mathrm{~W} /\left(\mathrm{K} \mathrm{m}^{2}\right)$ and $3.2 \mathrm{~W} /($ $\mathrm{m}^{2} \mathrm{~K}$ ) respectively. The building infiltration rate is $1 \mathrm{ACH}$.

We assume that future residential buildings will have more aggressive energy efficiency codes under the policy scenario. In 2030, the residential building code in China is assumed to reach the same level as ASHRAE standard (90.1 for high rise residential buildings) projected in that year. Residential building performance in intervening years assumes progressively more stringent measures based on the existing standard. The result of the simulation shows a $45 \%$ heating energy reduction and $18 \%$ cooling energy reduction with respect to current building codes. These parameters are summarized in Table 2.

\footnotetext{
${ }^{2}$ JGJ 26 for cold and severe cold climate zone, and JGJ 134

${ }^{3}$ Residential buildings in other climate zones are modeled accordingly, in compliance with the Chinese residential building code: JGJ 26, JGJ 134, and JGJ 75 . This description here only states the measures applied to residential buildings in HSCW climate region, but the building is modeled in all major Chinese climate regions.
} 
We modeled commercial building energy efficiency by analyzing reference office buildings with parameters determined by the Chinese commercial building code. The current Chinese commercial building code GB50189-2005 is used to model new construction. GB50189 also provides the characteristics of existing buildings built around 1980. Table 3 gives the building system characteristics in Shanghai (HSCW climate region) under different years. China currently has a less stringent commercial building code compared with ASHRAE standards. As in the case of residential buildings, we assume that Chinese commercial building codes catch up with ASHRAE standards by 2030 in the policy scenario and model improvement in intervening years similarly. The result of the simulation shows a $50 \%$ heating energy reduction and $40 \%$ cooling energy reduction with respect to current building codes.

\section{TABLE 3 - COMMERCIAL BUILDING PARAMETERS - HSCW CLIMATE REGION}

For both residential and building codes, only the policy's impacts on heating and cooling loads are modeled and code requirements and potential savings related to lighting and equipment efficiency are not evaluated. 


\subsection{DISTRICT HEATING METERING AND CONTROLS (RESIDENTIAL)}

In northern China, district heating is the main source of heating during the winter. The typical district heating system in the building stock has few room thermostats. The heating fee is charged based on room floorspace rather than how much heat is used in one building. Due to this lack of control capability, building residents can not adjust their room set point or turn the heating off when they are not at home. One common phenomenon in northern China is that, because of the absence of room thermostat, rooms become over-heated and occupants open windows to cool down their rooms.

In the Severe Cold (SC) climate region, the heating season extends from October 15 to April 15; in the Cold (C) climate region, the heating season is from November 15 to March 15. The modeling of heating control assumes for existing building without terminal control system, that building room temperature is controlled at constant $25^{\circ} \mathrm{C}$ in the winter; while for new buildings with thermostat controls, the room temperature is controlled at $18^{\circ} \mathrm{C}$ and heating is off when occupants are absent weekdays from 8:00 am to $6: 00 \mathrm{pm}$. According to simulations, thermostat controls applied in this way could lower heating energy demand by approximately $40 \%$.

\subsection{DISTRICT HEATING EFFICIENCY IMPROVEMENT (RESIDENTIAL AND COMMERCIAL)}


In addition to reduction from consumption changes at the building level, the efficiency of district heating is considered. District heating can be improved at the central level through reduced transmission losses during pipelining, and reduction of losses at pumping stations.

District heating to Chinese residential and commercial districts is transported either directly through a single pipeline system (single-tier systems) or through a combination of primary and secondary systems with an intermediate pumping station (two-tier systems). Newly installed primary systems can be very efficient, with about 1-3\% losses, while worn and old circuit losses can be as high as 30\% (Zhong et al., 2011; Qi et al., 2008). The current Chinese standard requires that primary heating circuits be at least 90\% efficient (CABR, 2001). We assume that (1) the average efficiency for primary systems is $80 \%$ and can be improved to $91 \%$ and (2) the average efficiency for two-tier systems is $60 \%$ and can be improved to $81 \%$. Two-tier-systems are becoming less common in China as worn-out systems are replaced with 1-tier systems. We estimate the share of 2-tier systems at $20 \%$ in 2010 , decreasing to $10 \%$ in 2020 (Zhong et al., 2011; Qi et al., 2008).

In addition to heat losses through the pipeline, district heating systems also waste energy through inefficiencies in pumping systems at the pumping station due to suboptimal load matching. We assume that the average electricity intensity is $1.75 \mathrm{kWh}$ per $\mathrm{m}^{2}$ of floor space for a single-tier pump system and $2 \mathrm{kWh} / \mathrm{m}^{2}$ for a two-tier system 
(BERC, 2011). The electricity intensity can be reduced by $0.5 \mathrm{kWh} / \mathrm{m}^{2}$ through system optimization (BERC, 2011), or roughly $5 \%$ of the average heating load.

\subsection{ENERGY EFFICIENCY LABELS (RESIDENTIAL AND COMMERCIAL)}

China began promoting the voluntary use of whole building energy labels in the last few years and currently have a Green Building Evaluation and Labeling program and a Building Energy Efficiency Evaluation and Labeling Program, both of which are managed by the Ministry of Housing and Urban-Rural Development (MOHURD). The Building Energy Efficiency (BEE) labeling program evaluates buildings on a scale of one (least efficient) to five stars (most efficient) in terms of energy efficiency, with a focus on HVAC system efficiency, compulsory standard compliance, and optional building efficiency features. The Green Building labeling program covers a broader scope beyond energy that includes resource efficiency, indoor and outdoor environment criteria, land use and water efficiency (MOHURD, 2008). Because this report focuses on energy and energy-related $\mathrm{CO}_{2}$ emissions, only the $\mathrm{BEE}$ labeling program is taken into consideration in our modeling and policy evaluation efforts.

Although the BEE labeling program is relatively new, there have been concerted efforts to increase the penetration of efficient buildings through incentives and demonstration energy efficient and emission reduction provinces and cities as part of the $12^{\text {th }}$ FYP (MOF, 2011a, 2011b). In addition, ongoing research and policy discussions related to the BEE labeling program have focused on expanding building coverage, the use of 
economic incentives to raise labeling interest and awareness and further promotion of the program at provincial and city levels (CABR, 2001).

Short-term acceleration of the construction of so-called "green" buildings and even "net-zero energy" (NZE) buildings could provide additional short-term opportunities. In the 12th FYP, China has the following targets for green buildings:

- At least $80 \%$ government-invested public buildings and $70 \%$ of low-income housing buildings in provincial cities need to be green buildings by 2015 .

- $20 \%$ of new construction in key cities needs to be green buildings by 2015 .

The BEE label evaluates buildings based on three key components: the energy consumption of heating, air conditioning, and lighting systems per $\mathrm{m}^{2}$ in accordance with national building energy standards; compliance with minimum performance requirements for building enclosure and HVAC; and implementation of optional energy efficiency or renewable energy systems (Mo et al., 2011). To achieve the most efficient five-star rating, a building must achieve $85 \%$ HVAC and lighting energy savings relative to inefficient 1980s buildings, meet all minimum performance requirements and have incorporated a significant share of qualifying optional efficient and renewable systems (Cao, 2011). Because the current building standards require 50\% energy savings relative to the same baseline of inefficient buildings, a five-star rated building essentially saves $70 \%$ more energy relative to a comparable existing building in compliance with building standards. 
In this study, the most efficient five-star BEE rated buildings are thus modeled as achieving $70 \%$ energy savings in space heating for residential buildings, in HVAC for Southern residential buildings and in HVAC for all commercial buildings. Potential energy savings in lighting and equipment for the most efficient five-star BEE rated buildings are not modeled in this study. In light of the recently launched incentive policies for efficient buildings and ongoing policy discussions on expanding the BEE program, five-star rated efficient buildings are assumed to reach $10 \%$ share of new residential and commercial buildings by 2015, rising to $25 \%$ share by 2030 .

\subsection{BUILDING ENERGY RETROFITS (HSCW CLIMATE REGION) - (RESIDENTIAL AND} COMMERCIAL)

Residential building energy efficiency retrofits is mainly focused on northern China (Cold and Severe Cold climate region) and the HSCW climate region. The retrofit of residential buildings aims to improve building shell performance so it complies with the climate region's energy efficiency code. The before-retrofit building conditions are assumed at year 1980 as specified in Table 4 (for HSCW climate region), and the after-retrofit conditions are assumed to comply with what are specified in the current residential building code. The result of the simulation is a $25 \%$ heating and $10 \%$ cooling energy consumption reduction compared to 1980 building specifications.

\section{TABLE 4 - RESIDENTIAL BUILDING RETROFIT PARAMETER SUMMARY}


For commercial buildings, the HSCW climate region is taken as representative of the national average. Buildings in this climate region are assumed to have no insulation layer in the envelope before retrofit. Thus, the exterior wall, roof, and window U-values are $2.0 \mathrm{~W} /(\mathrm{m} 2 \mathrm{~K}), 1.5 \mathrm{~W} /(\mathrm{m} 2 \mathrm{~K})$ and $6.4 \mathrm{~W} /(\mathrm{m} 2 \mathrm{~K})$ respectively. Building infiltration rates are $2 \mathrm{ACH}$. After retrofit, the building's exterior wall, roof, and window U-values are improved to $1.0 \mathrm{~W} /(\mathrm{m} 2 \mathrm{~K}), 0.7 \mathrm{~W} /(\mathrm{m} 2 \mathrm{~K})$ and $3.0 \mathrm{~W} /(\mathrm{m} 2 \mathrm{~K})$, and the infiltration rate is reduced to $1 \mathrm{ACH}$. In the absence of district heating systems, boilers and electric chillers are the main heating and cooling equipment. Boiler efficiency is assumed to be $60 \%$ before retrofit and $80 \%$ after retrofit. Chiller COP value is assumed to improve from 4.0 to 4.8 after retrofit. Shanghai's climate conditions are used to evaluate building retrofits in the HSCW climate region. The result of the simulation is a $20 \%$ heating and $10 \%$ cooling energy consumption reduction compared to 1980 building specifications. These parameters are summarized in Table 5.

\section{TABLE 5 - COMMERCIAL BUILDING RETROFIT PARAMETER SUMMARY}

The parameters used to define the policy case, including heating and cooling savings and penetration rates of affected buildings are summarized in Table 6 . 
TABLE 6 - SUMMARY OF BUILDING POLICY MODELING PARAMETERS 


\subsection{POLICIES INTERACTIONS}

Since the effects of each policy on building energy demand are significant, it is important to carefully track the interactions and overlap between policies. In general, the impacts of each policy are lower when implemented in combination to another policy, since they act on an improved baseline. In order to quantify these interactions, we consider four policy combinations:

- Each Policy Individually - This combination does not take interactions between policies into account.

- All Policies Together - This combination takes into account all interactions between policies.

- New Buildings Only - Policies that affect new construction only - Building Codes and Energy Efficiency Labels

- Existing Buildings Only - Policies that affect existing buildings - District Heating Reform and Commercial Building Retrofits.

Accounting for the interaction between policies is straightforward. For example, if the efficiency improvement to heating from accelerated building codes is

$$
\phi(y)_{\text {Codes }}^{\text {heating }}
$$


And the efficiency improvement to heating from District Heating Metering and Controls

is

$$
\phi(y)_{\text {Metering }}^{\text {heating }}
$$

then the savings from both policies applied is given by

$$
E_{\text {policy }}^{i}(y)=E_{B A U}^{i}(y) \times \psi(y) \times\left(1-\phi(y)_{\text {Codes }}^{\text {heating }}\right) \times\left(1-\phi(y)_{\text {Metering }}^{\text {heating }}\right)
$$

In the next section, we show results according to the different policy considerations.

\section{Conclusions, Policy Implications and ReCOMmendations}

The above sections describe the determination of elements that are then brought together in order to calculate potential energy savings from each measure. The analysis begins with a reference case of energy demand in residential in commercial buildings according to a previous study by the authors (Zhou 2012). Calculation of energy savings potential then proceeds via a spreadsheet analysis that combines the parameters in Table 6 with reference energy intensities and projections of stock and construction and the equations provided in Section 4. Energy savings calculations in each year of the forecast are made separately for each policy, for new and existing buildings, and by sector. 
Results of these calculations are given in terms of primary energy are in Table 7 . The potential $\mathrm{CO}_{2}$ emissions impact of building policies were then evaluated by multiplying the final residential and commercial energy demand and savings by annual $\mathrm{CO}_{2}$ emissions factors for electricity, gas, coal and district heat. These results are also summarized in Table 7.

TABLE 7. POTENTIAL ENERGY IMPACTS OF BUILDING POLICIES - PRIMARY ENERGY AND EMISSIONS

Some high-level results emerge from the detailed modeling of individual policies:

- Building codes are the most impactful policy considered for both building types, accounting for over half of all savings (Figure 1).

- The next more impactful policies are heating reform from metering and controls in residential buildings and labeling in commercial buildings. Each of these policies could save around 100 Mtce cumulatively over the period 2015 to 2030 (Table 7) and 12.3 and 12.6 Mtce annual savings in 2030 respectively (Figure 1).

- Savings from all policies for residential buildings are similar to commercial buildings. 
- Overlap between policies is moderate. Savings from all combined policies together is $6 \%$ less than the sum of individual policies.

- Most of the savings (83\%) can be achieved by policies that affect new buildings.

FIGURE 1. 2030 ANNUAL ENERGY SAVINGS IN MTCE.

\subsection{BARRIERS AND RECOMMENDATIONS}

A recent study by the authors considered recommendations for development and enforcement of building energy efficiency policies in China (Feng et al., 2015). Details are not repeated here, but some important recommendations are drawn from that study.

Building Codes - In terms of primary energy, by far the largest savings is from the implementation of building codes. This is mainly because building codes impact all new buildings. Although the high construction rates China has seen in recent years is expected to peak and slow (already happened), due to continued urbanization, $32 \%$ of the residential building stock and 59\% of the commercial building stock in 2030 will have been built in 2015 or later. Building codes have the potential to become gradually more stringent, leading to $45 \%$ reductions in space heating loads for buildings built in 2030 . 
These two factors together lead to an overall $17 \%$ reduction in overall space heating and cooling demand relative to the baseline. The large savings yielded by building codes is driven by the assumption that these codes can be continually tightened in a process that reaches alignment with and keeps up with international best practices. This will require significant technical capacity in order to develop code specification, and adapt best practices to Chinese construction patterns and available technologies (Levine et, 2012). As (Zhou et al. 2012) demonstrated, enforcement of existing codes accounted for about the same amount of savings toward $11^{\text {th }}$ FYP goals as did the establishment of those codes. In an environment of ever more stringent codes, enforcement will remain a top priority in order to lose much of the savings to "leakage" effects. A key element of improved building codes enforcement will be standardization of building simulations and methods to evaluate measure impacts. While compliance rates have shown a dramatic improvement in recent years due to tightening enforcement processes in China's largest cities. However, compliance is generally much lower in smaller cities and rural areas. Therefore, we recommend that more attention be paid to extending compliance gains achieved in the largest cities to these sectors as well. Bridging this gap is largely an issue of building technical capacity to enable mayors of smaller cities and their enforcement staff to adequately enforce codes.

Energy Labels - Second in overall potential are energy efficiency labels. Energy efficiency labels could save about $6 \%$ in heating and cooling relative to the baseline, or about a third of building codes. As with other nascent programs, China's building energy efficiency labeling program suffers from relatively high transaction costs, due to 
a shortage of technical experts qualified to use the modeling software needed to evaluate building efficiency performance. In addition, incentives for builders are low. In order to overcome these barriers, we recommend a broad set of incentives, financial and otherwise from both government and private sector. In addition, governments have a role to play in leading by example, by requiring that public buildings exceed mandatory energy efficiency codes. These actions may serve to catalyze the market for labeled buildings and thereby also drive an increase in qualified experts to certify them.

District Heating - Reductions of losses associated with district heating represent a similar potential to labels, with about a $4 \%$ reduction. A large majority of this savings arises from retrofitting heating controls in residential buildings to give the occupants the ability to regulate the thermostat. Despite the significant energy savings potential afforded by retrofitting heating controls in residential buildings, these measures have proven difficult to achieve, as acknowledged by a recent survey of district heating systems in China (Xu et al., 2014). Challenges include economic, organizational, behavioral, managerial and financial barriers. The authors recommend that fiscal incentives and penalties are an important factor to make large-scale retrofits more viable. In addition, they argue that a more fair competitive market for energy services through increased access and regulation as well as carbon trading schemes would incentivize energy efficiency investment by enterprises selling heating services.

Retrofits - Finally, retrofits represent only about a $1 \%$ savings because although the savings for each individual building can be quite large, high costs lead to an assumption that only a small fraction of the building stock are feasible to retrofit. 
Our previous paper detailing the stated goals and progress in buildings efficiency during the 11th FYP (Zhou et al., 2012) concluded that Chinese policymakers and implementing agencies were on track to meet those goals by 2010 . The energy impact of the stated goals was estimated at roughly 90 Mtce cumulative between 2005 and 2010. The majority of those savings (62 Mtce) were achieved by the successful tightening of enforcement of existing building codes. In the 2015-2030 period, we estimate a cumulative savings of 980 Mtce to be possible, or over 10 times as much in a period only three times as long. As in the previous case, the majority of the savings are from building codes. While this is an admittedly ambitious target, it does not require not-yetcommercialized technologies and relies on a policy tool that is already well-known and has had great impact in China. The study detailed here takes a medium to long-term perspective, focusing on potential savings starting in 2015 and extending through 2030. To some degree this perspective logically leads to an emphasis in efficiency programs that affect new buildings, since so much of the building stock in 2030 will have been built during the 2015-2030 period.

\section{Acknowledgement}

This work was funded by a Laboratory Directed Research and Development grant under Contract No. DE-AC02-05CH11231. Any errors or omissions are the authors' own. 


\section{REFERENCES}

Building Energy Research Centre of Tsinghua University (BERC). 2011. Annual Report on Research Development of China Building Efficiency. Beijing: China Architect and Building Press.

Cao, Y.. 2011. Building Energy Efficiency Evaluation \& Labeling Technologies in China. Presentation at the Second U.S.-China Energy Efficiency Forum (May 5-6, 2011). Berkeley, CA.

China Academy of Building Research (CABR). 2001. JGJ132-2001: Standard for Energy Efficiency Inspection of Heating Residential Buildings (in Chinese). Beijing: China Architect and Building Press.

China Energy Research Institute. 2009. 2050 China Energy and $\mathrm{CO}_{2}$ Emissions Report (CEACER). Beijing: Science Press, In Chinese.

Feng, Wei, N. Zhou, S. de la Rue du Can, M. Bendewald and E. Franconi. Building Energy Codes in China: Recommendations for Development and Enforcement. CEO Council for Sustainable Urbanization. 2015.

IEA. 2013. World Energy Outlook 2013. Paris: International Energy Agency.

IEA, 2015. Building Energy Use in China: Transforming Construction and Influencing Consumption to 2050. IEA publication in collaboration with Tsinghua University Building $\begin{array}{llll}\text { Energy } & \text { Research } & \text { Center } & \text { (BERC). }\end{array}$ 
https://www.iea.org/publications/freepublications/publication/PARTNERCOUNTRYSERIESBu ildingEnergy WEB FINAL.pdf

Levine, M., S. de la Rue du Can, N. Zheng, C. Williams, J. Amann, and D. Staniaszek. 2012. Building Energy-Efficiency Best Practice Policies and Policy Packages. Lawrence Berkeley National Laboratory (LBNL) and Global Buildings Performance Network (GBPN). http://eetd.lbl.gov/sites/all/files/publications/gbpn-finaloct-2012.pdf.

Li J. and B. Shui. 2015. A comprehensive analysis of building energy efficiency policies in China: status quo and development perspective. Journal of Cleaner Production 90 (2015) 326-344

McNeil, M., V. Letschert and S. de la Rue du Can 2008. Global Potential of Energy Efficiency Standards and Labeling Programs, LBNL-760E.

McNeil, M., Letschert, V., de la Rue du Can, S., Ke, J., 2013. Bottom-Up Energy Analysis System (BUENAS)-an international appliance efficiency policy tool. Energy Efficiency, 1-27.

McKinsey \& Company. 2009. China's Green Revolution: Prioritizing technologies to achieve energy and environmental sustainability. Shanghai: McKinsey \& Company.

Ministry of Finance (MOF). 2011a. Further Notice on Public Buildings' Energy Efficiency Efforts. MOF No. 207. 
Ministry of Finance (MOF). 2011b. Fiscal Policy for Energy Efficient and Emission Reduction Demonstration Provinces and Cities. MOF No. 383.

Mo, K., Burt, L., Hao, B., Cheng, L., Burr, A., \& Kemkar, S. 2010. Comparative Analysis of U.S. and China Labeling Energy Rating and Labeling Programs. Proceedings of the 2010 ACEEE Summer Study on Energy Efficiency in Buildings. Pacific Grove.

Ministry of Housing and Urban-Rural Development (MOHURD). 2008. Management Methods for Green Building Evaluation and Certification (in Chinese). Beijing: MOHURD.

Qi, S.H., Wang, X.L., Han, R.X. 2008. "Approaches to improve energy utilization efficiency of centralized heat-supply system (in Chinese)." Gas \& Heat 28 (12): 31-33.

Xiao H., Q. Wei, H. Wang, 2014. "Marginal abatement cost and carbon reduction potential outlook of key energy efficiency technologies in China's building sector to 2030", EnergyPolicy69(2014)92-105

Xu, X., S. You, X. Zheng, and H. Li. "A survey of district heating systems in the heating regions of Northern China. Energy 77 2014: 909-925. 
Yu, S., Eom, J., Zhou, Y., Evans, M., Clarke, L. 2014. "Scenarios of building energy demand for China with a detailed regional representation," Energy 67 : 284-297.

Zhong, K., He, X., Wang, M., Liu, P., Yang, X. 2011. “Transport efficiency calculation and energy-saving reconstruction of heat-supply network (in Chinese)." Gas \& Heat 31 (6): 16-18.

Zhou, Nan, Michael A. McNeil, David Fridley, Jieming Lin, Lynn K. Price, Stephane de la Rue du Can, Jayant A. Sathaye, and Mark D. Levine. 2007. Energy Use in China: Sectoral Trends and Future Outlook. LBNL-61904. Lawrence Berkeley National Laboratory, 2007.

Zhou, N., D. Fridley, M.A. McNeil, N. Zheng, J. Ke. and M. Levine. 2011a. China's Energy and Carbon Emissions Outlook. LBNL- 4472E. Berkeley, CA: Lawrence Berkeley National Laboratory.

Zhou, N., Fridley, D., McNeil, M., Zheng, N., Letschert, V., Ke, J. and Y. Saheb. 2011b. "Analysis of Potential Energy Saving and $\mathrm{CO}_{2}$ Emission Reduction of Home Appliances and Commercial Equipments in China." Energy Policy 39 (8): 4541-4550. 
Zhou, N., M. McNeil and M. Levine. 2012. "Assessment of building energy-saving policies and programs in China during the $11^{\text {th }}$ Five-Year Plan." Energy Efficiency 2012 5:5164. 
TABLE 1 - MACROECONOMIC DRIVER ASSUMPTIONS FOR ALL SCENARIOS

\begin{tabular}{|l|l|l|}
\hline & $\mathbf{2 0 0 5}$ & $\mathbf{2 0 3 0}$ \\
\hline Population & 1.31 Billion & 1.46 Billion \\
\hline Urbanization Rate & $43 \%$ & $70 \%$ \\
\hline GDP Growth & \multicolumn{2}{|l|}{} \\
\hline $\mathbf{2 0 1 0 - 2 0 2 0}$ & $7.7 \%$ per year \\
\hline $\mathbf{2 0 2 0 - 2 0 3 0}$ & 5.9\% per year \\
\hline
\end{tabular}

TABLE 2- RESIDENTIAL CODE PARAMETER ASSUMPTIONS- HSCW CLIMATE REGION

\begin{tabular}{|c|c|c|c|c|c|}
\hline \multirow[t]{3}{*}{ Year } & \multicolumn{5}{|c|}{ Envelope } \\
\hline & \multirow{2}{*}{$\begin{array}{c}\text { Roof U } \\
{\left[\mathrm{W} / \mathrm{m}^{2} \mathrm{~K}\right]}\end{array}$} & \multirow{2}{*}{$\begin{array}{c}\text { Wall U } \\
{\left[\mathrm{W} / \mathrm{m}^{2} \mathrm{~K}\right]}\end{array}$} & \multicolumn{2}{|r|}{ Window } & \multirow{2}{*}{$\begin{array}{c}\text { Infiltratior } \\
\text { [ACH] }\end{array}$} \\
\hline & & & $\mathrm{U}\left[\mathrm{W} / \mathrm{m}^{2} \mathrm{~K}\right]$ & Solar heat gain coefficient (SHGC) & \\
\hline After 1980 & 1.50 & 2.00 & 6.40 & 0.95 & 2.0 \\
\hline 2004 & 0.70 & 1.00 & 3.00 & 0.5 & 1.0 \\
\hline 2010 & 0.65 & 0.9 & 2.8 & 0.4 & 0.6 \\
\hline 2020 & 0.45 & 0.6 & 2.5 & 0.36 & 0.4 \\
\hline 2030 & 0.35 & 0.4 & 2 & 0.33 & 0.2 \\
\hline
\end{tabular}


TABLE 3 - COMMERCIAL BUILDING PARAMETERS - HSCW CLIMATE REGION

\begin{tabular}{|c|c|c|c|c|c|c|c|c|}
\hline \multirow[t]{3}{*}{ Year } & \multicolumn{5}{|c|}{ Envelope } & \multicolumn{3}{|c|}{ HVAC } \\
\hline & \multirow{2}{*}{$\begin{array}{l}\text { Roof U } \\
{\left[W / m^{2}\right.} \\
K\end{array}$} & \multirow{2}{*}{$\begin{array}{l}\text { Wall U } \\
{\left[\begin{array}{l}\mathrm{W} / \mathrm{m} \\
\left.{ }^{2} \mathrm{~K}\right]\end{array}\right.}\end{array}$} & \multicolumn{2}{|c|}{ Window } & \multirow{2}{*}{$\begin{array}{c}\text { Infiltration } \\
{[\mathrm{ACH}]}\end{array}$} & \multirow{2}{*}{$\begin{array}{c}\text { Chiller } \\
\text { coefficient } \\
\text { of } \\
\text { performanc } \\
\text { e (COP) }\end{array}$} & \multirow{2}{*}{$\begin{array}{c}\text { Boiler } \\
\text { efficiency }\end{array}$} & \multirow[t]{2}{*}{ System types } \\
\hline & & & $\underset{\substack{\left.\mathrm{W} / \mathrm{m} \\
{ }^{2} \mathrm{~K}\right]}}{c}$ & SHGC & & & & \\
\hline $\begin{array}{l}\text { After } \\
1980\end{array}$ & 1.50 & 2.00 & 6.40 & 0.95 & 2.0 & 4.00 & 0.58 & Fan-coil unit (FCU) \\
\hline 2004 & 0.70 & 1.00 & 3.00 & 0.5 & 1.0 & 4.80 & 0.78 & FCU \\
\hline 2010 & 0.55 & 0.8 & 2.8 & 0.4 & 0.6 & 5.3 & 0.83 & FCU, Economizers \\
\hline 2020 & 0.45 & 0.6 & 2.5 & 0.36 & 0.4 & 5.7 & 0.87 & $\begin{array}{l}\text { Radiant panel, } \\
\text { Economizers }\end{array}$ \\
\hline 2030 & 0.35 & 0.4 & 2 & 0.33 & 0.2 & 6.2 & 0.91 & $\begin{array}{l}\text { Radiant panel, } \\
\text { Economizers, } \\
\text { Natural Ventilation }\end{array}$ \\
\hline
\end{tabular}

TABLE 4 - RESIDENTIAL BUILDING RETROFIT PARAMETER SUMMARY

\begin{tabular}{|l|c|c|c|c|c|}
\hline \multirow{2}{*}{} & \multicolumn{5}{|c|}{ Envelope } \\
\cline { 2 - 5 } & $\begin{array}{c}\text { Roof U } \\
{\left[\mathbf{W} / \mathbf{m}^{2} \mathbf{K}\right]}\end{array}$ & $\begin{array}{c}\text { Wall U } \\
{\left[\mathbf{W} / \mathbf{m}^{2} \mathbf{K}\right]}\end{array}$ & \multicolumn{2}{|c|}{ Window } & Infiltration \\
\cline { 4 - 5 } & & & $\mathbf{U}\left[\mathbf{W} / \mathbf{m}^{2} \mathbf{K}\right]$ & SHGC & \\
\hline Before retrofit & 1.50 & 2.00 & 6.40 & 0.95 & 2.0 \\
\hline After retrofit & 0.70 & 1.00 & 3.00 & 0.5 & 1.0 \\
\hline
\end{tabular}


TABLE 5 - COMMERCIAL BUILDING RETROFIT PARAMETER SUMMARY

\begin{tabular}{|c|c|c|c|c|c|c|c|}
\hline & \multicolumn{5}{|c|}{ Envelope } & \multicolumn{2}{|c|}{ HVAC } \\
\hline & \multirow{2}{*}{$\begin{array}{c}\text { Roof U } \\
{\left[\mathrm{W} / \mathrm{m}^{2} \mathrm{~K}\right]}\end{array}$} & \multirow{2}{*}{$\begin{array}{c}\text { Wall U } \\
{\left[\mathrm{W} / \mathrm{m}^{2} \mathrm{~K}\right]}\end{array}$} & \multicolumn{2}{|c|}{ Window } & \multirow{2}{*}{$\begin{array}{c}\text { Infiltration } \\
{[\mathrm{ACH}]}\end{array}$} & \multirow{2}{*}{$\begin{array}{c}\text { Chiller } \\
\text { COP }\end{array}$} & \multirow{2}{*}{$\begin{array}{c}\text { Boiler } \\
\text { efficiency }\end{array}$} \\
\hline & & & $U\left[W / m^{2} K\right]$ & SHGC & & & \\
\hline Before retrofit & 1.50 & 2.00 & 6.40 & 0.95 & 2.0 & 4.00 & 0.60 \\
\hline After retrofit & 0.70 & 1.00 & 3.00 & 0.5 & 1.0 & 4.80 & 0.80 \\
\hline
\end{tabular}


TABLE 6 - SUMMARY OF BUILDING POLICY MODELING PARAMETERS

\begin{tabular}{|c|c|c|c|c|c|c|c|c|}
\hline \\
\hline Policy & Sector & Variable & Scope & Modeling Parameter & 2015 & 2020 & 2025 & 2030 \\
\hline \multirow{6}{*}{$\begin{array}{l}\text { Accelerated Building } \\
\text { Codes }\end{array}$} & \multirow{3}{*}{ Res. } & $\phi(y)^{\text {heating }}$ & \multirow{3}{*}{$\begin{array}{l}\text { New } \\
\text { Buildings }\end{array}$} & \multirow{2}{*}{$\begin{array}{l}45 \% \text { heating energy and } 18 \% \text { cooling energy reduction } \\
\text { compared to current buildings code by } 2030 \text {. Based on } \\
\text { simulation. }\end{array}$} & $15 \%$ & $28 \%$ & $37 \%$ & $45 \%$ \\
\hline & & $\phi(y)^{\text {cooling }}$ & & & $6 \%$ & $11 \%$ & $15 \%$ & $18 \%$ \\
\hline & & $\psi(y)$ & & All new buildings affected & $100 \%$ & $100 \%$ & $100 \%$ & $100 \%$ \\
\hline & \multirow{3}{*}{ Com. } & $\phi(y)^{\text {heating }}$ & \multirow{3}{*}{$\begin{array}{l}\text { New } \\
\text { Buildings }\end{array}$} & \multirow{2}{*}{$\begin{array}{l}50 \% \text { heating energy and } 40 \% \text { cooling energy reduction } \\
\text { compared to current buildings code by } 2030 \text {. Based on } \\
\text { simulation. }\end{array}$} & $32 \%$ & $42 \%$ & $46 \%$ & $50 \%$ \\
\hline & & $\phi(y)^{\text {cooling }}$ & & & $22 \%$ & $32 \%$ & $32 \%$ & $40 \%$ \\
\hline & & $\psi(y)$ & & All new buildings affected. & $100 \%$ & $100 \%$ & $100 \%$ & $100 \%$ \\
\hline \multirow{2}{*}{$\begin{array}{l}\text { District Heating Metering } \\
\text { and Controls }\end{array}$} & \multirow[t]{2}{*}{ Res. } & $\phi(y)^{\text {heating }}$ & \multirow{2}{*}{$\begin{array}{l}\text { Existing } \\
\text { Buildings }\end{array}$} & $\begin{array}{l}\text { Setpoint reduced from } 22-25 \mathrm{C} \text { to } 18 \mathrm{C} \text {. Heating off when } \\
\text { unoccupied. Based on simulation. }\end{array}$ & $40 \%$ & $40 \%$ & $40 \%$ & $40 \%$ \\
\hline & & $\psi(y)$ & & Half of currently unmetered buildings retrofit by 2030 . & $0 \%$ & $16 \%$ & $32 \%$ & $50 \%$ \\
\hline \multirow[t]{2}{*}{$\begin{array}{l}\text { District Heating Efficiency } \\
\text { Improvement }\end{array}$} & \multirow[t]{2}{*}{ Res. } & $\phi(y)^{\text {heating }}$ & \multirow[t]{2}{*}{$\begin{array}{l}\text { All } \\
\text { Buildings }\end{array}$} & $\begin{array}{l}\text { Single-tier improvement } 80 \% \text { to } 91 \% \text { efficiency. Two-tier } \\
\text { improvement } 60 \% \text { to } 81 \% \text { efficiency. } 5 \% \text { pump system } \\
\text { efficiency improvement. }\end{array}$ & $21 \%$ & $21 \%$ & $21 \%$ & $21 \%$ \\
\hline & & $\psi(y)$ & & Retrofit of 80 million m2 per year starting 2015. & $1 \%$ & $6 \%$ & $11 \%$ & $16 \%$ \\
\hline \multirow{6}{*}{ Energy Efficiency Labels } & \multirow{3}{*}{ Res. } & $\phi(y)^{\text {heating }}$ & \multirow{6}{*}{$\begin{array}{l}\text { New } \\
\text { Buildings }\end{array}$} & \multirow{2}{*}{$\begin{array}{l}\text { Definitions of } 5 \text { Star include } 70 \% \text { heating and } 80 \% \text { cooling } \\
\text { improvement relative to } 1980 \text { buildings. }\end{array}$} & $70 \%$ & $70 \%$ & $70 \%$ & $70 \%$ \\
\hline & & $\phi(y)^{\text {cooling }}$ & & & $80 \%$ & $80 \%$ & $80 \%$ & $80 \%$ \\
\hline & & $\psi(y)$ & & $10 \%$ of new buildings in 2015 increasing to $25 \%$ in 2030. & $10 \%$ & $15 \%$ & $20 \%$ & $25 \%$ \\
\hline & \multirow{3}{*}{ Com. } & $\phi(y)^{\text {heating }}$ & & \multirow{2}{*}{$\begin{array}{l}\text { Definitions of } 5 \text { Star include } 70 \% \text { heating and } 80 \% \text { cooling } \\
\text { improvement relative to } 1980 \text { buildings. }\end{array}$} & $70 \%$ & $70 \%$ & $70 \%$ & $70 \%$ \\
\hline & & $\phi(y)^{\text {cooling }}$ & & & $80 \%$ & $80 \%$ & $80 \%$ & $80 \%$ \\
\hline & & $\psi(y)$ & & $10 \%$ of new buildings in 2015 increasing to $25 \%$ in 2030. & $10 \%$ & $15 \%$ & $20 \%$ & $25 \%$ \\
\hline \multirow{3}{*}{ Retrofits } & \multirow{3}{*}{ Res. } & $\phi(y)^{\text {heating }}$ & \multirow{3}{*}{$\begin{array}{l}\text { Existing } \\
\text { Buildings }\end{array}$} & \multirow{2}{*}{$\begin{array}{l}25 \% \text { heating energy and } 10 \% \text { cooling energy reduction } \\
\text { compared to } 1980 \text { codes. Based on simulation. }\end{array}$} & $25 \%$ & $25 \%$ & $25 \%$ & $25 \%$ \\
\hline & & $\phi(y)^{\text {cooling }}$ & & & $10 \%$ & $10 \%$ & $10 \%$ & $10 \%$ \\
\hline & & $\psi(y)$ & & Goal of 400 million m2 per year (FYP 13 goal). & $1 \%$ & $4 \%$ & $6 \%$ & $6 \%$ \\
\hline \multirow{3}{*}{ Retrofits } & \multirow{3}{*}{ Com. } & $\phi(y)^{\text {heating }}$ & \multirow{3}{*}{$\begin{array}{l}\text { All } \\
\text { Buildings }\end{array}$} & \multirow{2}{*}{$\begin{array}{l}20 \% \text { heating energy and } 10 \% \text { cooling energy reduction } \\
\text { compared to } 1980 \text { codes. Based on simulation. }\end{array}$} & $20 \%$ & $20 \%$ & $20 \%$ & $20 \%$ \\
\hline & & $\phi(y)^{\text {cooling }}$ & & & $10 \%$ & $10 \%$ & $10 \%$ & $10 \%$ \\
\hline & & $\psi(y)$ & & Retrofit of all pre-2000 buildings by 2030 . & $0.4 \%$ & $2 \%$ & $4 \%$ & $5 \%$ \\
\hline
\end{tabular}


TABLE 7. POTENTIAL ENERGY IMPACTS OF BUILDING POLICIES - PRIMARY ENERGY AND EMISSIONS

\begin{tabular}{|c|c|c|c|c|c|c|}
\hline \multirow[b]{2}{*}{ Policy } & \multicolumn{3}{|c|}{ Primary Energy (mtce) } & \multicolumn{3}{|c|}{$\mathrm{CO}_{2}$ Emissions $\left(\mathrm{mt} \mathrm{CO}_{2}\right)$} \\
\hline & 2010 & 2030 & Cumulative & 2010 & 2030 & Cumulative \\
\hline \multicolumn{7}{|c|}{ Residential } \\
\hline \multicolumn{7}{|c|}{ BAU Scenario } \\
\hline Heating & 120.0 & 185.1 & & 566.5 & 552.9 & \\
\hline Cooling & 26.3 & 35.6 & & 56.2 & 59.3 & \\
\hline All HVAC & 146.3 & 220.7 & & 622.6 & 612.2 & \\
\hline \multicolumn{7}{|c|}{ Savings / Mitigation } \\
\hline Building Codes & & 29.5 & 263.7 & & 85.0 & 843.4 \\
\hline Heating Reform - Controls & & 12.3 & 103.8 & & 43.2 & 398.0 \\
\hline Heating Reform - Plant \& Transmission Efficiency & & 2.1 & 19.0 & & 7.2 & 73.3 \\
\hline Energy Efficiency Labels & & 10.9 & 93.4 & & 29.7 & 280.0 \\
\hline Retrofits & & 3.2 & 34.2 & & 9.2 & 110.6 \\
\hline Total Individual & & 58.0 & 513.9 & & 174.3 & $\mathbf{1 7 0 5 . 4}$ \\
\hline All Policies & & 52.5 & 478.0 & & 152.6 & 1531.1 \\
\hline Existing Buildings & & 16.7 & 150.1 & & 51.3 & 498.3 \\
\hline New Buildings & & 38.8 & 346.1 & & 110.6 & 1095.9 \\
\hline \multicolumn{7}{|c|}{ Commercial } \\
\hline \multicolumn{7}{|c|}{ BAU Scenario } \\
\hline Heating & 75.3 & 103.0 & & 245.7 & 288.6 & \\
\hline Cooling & 35.1 & 62.0 & & 161.2 & 231.3 & \\
\hline All HVAC & 110.4 & 165.0 & & 406.9 & 519.9 & \\
\hline \multicolumn{7}{|c|}{ Savings / Mitigation } \\
\hline Building Codes & & 35.3 & 306.1 & & 108.9 & 945.6 \\
\hline Heating Reform - Plant \& Transmission Efficiency & & 1.0 & 7.8 & & 2.5 & 19.8 \\
\hline Energy Efficiency Labels & & 12.6 & 100.5 & & 24.7 & 195.4 \\
\hline Retrofits & & 1.3 & 10.9 & & 3.9 & 33.0 \\
\hline Total Individual & & 50.3 & 425.4 & & 140.0 & 1193.8 \\
\hline All Policies & & 46.9 & 405.3 & & 143.6 & 1242.3 \\
\hline Existing Buildings & & 2.3 & 18.6 & & 3.9 & $\mathbf{3 3 . 0}$ \\
\hline New Buildings & & 45.3 & 390.7 & & 140.8 & 1216.1 \\
\hline \multicolumn{7}{|c|}{ Total } \\
\hline \multicolumn{7}{|c|}{ BAU Scenario } \\
\hline Heating & 195.2 & 288.0 & & 812.1 & 841.4 & \\
\hline Cooling & 61.5 & 97.6 & & 217.4 & 290.6 & \\
\hline All HVAC & 256.7 & 385.6 & & 1029.5 & 1132.1 & \\
\hline \multicolumn{7}{|c|}{ Savings / Mitigation } \\
\hline Building Codes & & 64.8 & 569.8 & & 193.9 & 1789.0 \\
\hline Heating Reform - Controls & & 12.3 & 103.8 & & 43.2 & 398.0 \\
\hline Heating Reform - Plant \& Transmission Efficiency & & 3.0 & 26.7 & & 9.7 & 93.2 \\
\hline Energy Efficiency Labels & & 23.6 & 193.9 & & 54.4 & 475.4 \\
\hline Retrofits & & 4.5 & 45.1 & & 13.1 & 143.7 \\
\hline Total Individual & & 108.2 & 939.3 & & 314.3 & 2899.2 \\
\hline All Policies & & 99.4 & 883.3 & & 296.2 & 2773.3 \\
\hline Existing Buildings & & 19.0 & 168.7 & & 55.3 & 531.3 \\
\hline New Buildings & & 84.1 & 736.8 & & 251.4 & 2311.9 \\
\hline
\end{tabular}


Figure(s)

\section{FIGURES}

FIGURE 1. 2030 ANNUAL ENERGY SAVINGS IN MTCE.

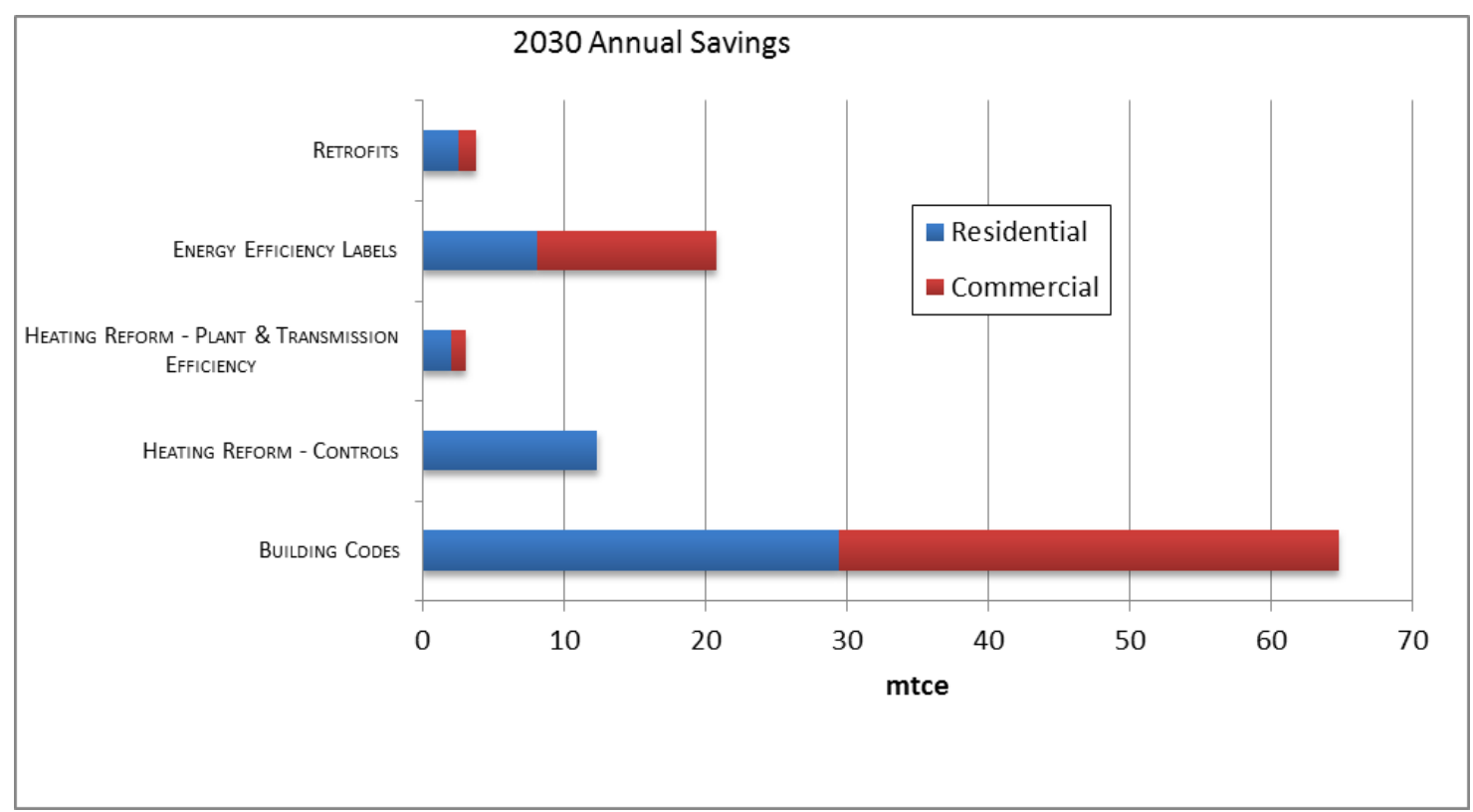

